\title{
Coastal Vegetation Diversity on Baai Island, Kampung Melayu District, Bengkulu City
}

\author{
Fatimatuzzahra $^{1, *}$, Jarulis $^{1}$, Rochmah Supriati ${ }^{1}$ \\ ${ }^{I}$ Department of Biology, Faculty of Mathematics and Natural Sciences, Universitas of Bengkulu, Kandang Limun, \\ Bengkulu 38112, Indonesia \\ *Corresponding author. Email: fatimatuzzahra@unib.ac.id
}

\begin{abstract}
BAAI Island has a coastal forest formed from various communities and vegetation structures, which have functions including as a tourist area, a source of food, and disaster mitigation. The aim of this research was to find out the composition, structure and diversity of coastal vegetation on Baai Island area, west of Sumber Jaya Village, Kampung Melayu District, Bengkulu City. Sampling was taken using the transect line plot method with a size of $20 \times 20 \mathrm{~m}$ for trees, $10 \times 10 \mathrm{~m}$ for poles, a plot size of $5 \times 5 \mathrm{~m}$ for saplings. The results showed that the composition of the coastal vegetation at the tree level found 11 families, with a total of 11 species. 5 species came from the pole level, and 4 species with a total of 11 individuals from the sapling level. The species of Casuarina equisetifolia obtained the highest value index of importance at the tree level, while the species Ardisia elliptica had the important value index for the stakes and saplings. The results of the calculation of the Shannon-Wiener diversity index $\left(\mathrm{H}^{\prime}\right)$, of all growth levels show a value $<1.0$ which means low diversity, less stable.
\end{abstract}

Keywords: Baai Island, Coastal vegetation, Diversity

\section{INTRODUCTION}

Bengkulu is a province in Indonesia which borders the Indian Ocean to the west. It has natural tourism areas, one of which is Baai Island which is a conservation area under the supervision of the Bengkulu Natural Resources Conservation Center [1]. BAAI Island has coastal forest vegetation. As is well known, coastal forests are generally located in the coastal part (the boundary between land and sea).

Coastal forests can occur due to the influence of waves and winds which have an impact on the accumulation of sand towards the land which in a certain time can be overgrown by plants to form a community to the coastal ecosystem. Coastal forests, which consist of coastal vegetation, can function as providers of productive natural resources such as food sources,

vegetation. Whereas the width of the forest is one of the determining factors in disaster mitigation [2]. So it is necessary to carry out a sustainable vegetation analysis in order to determine the diversity of vegetation that supports the growth of coastal forests. Thus, the data obtained can provide input to related researchers in order producers of high economic value drugs, mineral and energy mining, as well as recreational areas or coastal tourism as well as the discovery of biochemical products [2]. However, day by day, the condition of the coastal forest ecosystem can experience a decline, which is caused by various factors such as logging, settlement, environmental changes, coastal abrasion.

The beaches most vulnerable to natural disasters such as tsunami hazards are those with the lowest open coastal plains [2]. As reported in related journals, abrasion disasters that occur near the coast near the city of Bengkulu have a speed of $0.5-1 \mathrm{~m} / \mathrm{yr}$ [3] and can destroy vegetation, especially those facing the Indian Ocean [3] [4]. In addition, there is clearing land to industrial purposes in the west of the Baai Island natural tourism area, which is believed to directly or indirectly affect changes in coastal forests including the surrounding

to support the conservation of coastal forests in the west of Sumber Jaya Village, Kampung Melayu District, Baai Island Area, Bengkulu City. 


\section{METHODS}

Data collection was carried out in August-November 2020 in the west of Sumber Jaya Village, Kampung Melayu District, Baai Island Area, Bengkulu City. Sampling was taken using the transect line plot method with a size of $20 \times 20 \mathrm{~m}$ for trees observations, $10 \times 10 \mathrm{~m}$ for poles, 5 x $5 \mathrm{~m}$ plot size for saplings.

\subsection{Measurement}

Measurements are made based on the level of vegetation growth [5], which are as follows:

1. Vegetation tree level: the type of vegetation, vegetation height, diameter at breast height (diameter $\geqslant 20 \mathrm{~cm}$ )

2. Vegetation poles: types of vegetation, vegetation height, diameter at breast height $(10 \mathrm{~cm}>$ diameter $<20 \mathrm{~cm}$ )

3. Vegetation saplings: the type of vegetation, provided high $>150 \mathrm{~cm}$, stem diameter $<10 \mathrm{~cm}$.

\subsection{Data Analysis}

The data obtained were then processed, the density $(\mathrm{K})$, relative density (KR), frequency $(\mathrm{F})$, relative frequency (FR), dominance (D), and relative dominance
(DR) were calculated. Thus, we obtained the importance value index and Shannon-Wiener diversity index $\left(\mathrm{H}^{\prime}\right)$.

$\mathrm{H}^{\prime}=-\sum \frac{\mathrm{ni}}{\mathrm{N}} \log \frac{\mathrm{ni}}{\mathrm{N}}$

Where $\mathrm{H}$ 'is the Shannon-Wiener Diversity Index with ni is the number of a species $\mathrm{i}$, and $\mathrm{N}$ is the total number of individuals of all species. If the value of $\mathrm{H}^{\prime}<1$, indicates species diversity on a transect, it is low/ less stable. If the value of $\mathrm{H}^{\prime} 1 \leqslant \mathrm{H}^{\prime} \leqslant 3$ means that the diversity of species on a transect is abundant. If the value of $\mathrm{H}^{\prime}$ > indicates that species diversity, high abundance / more stable [6].

\section{RESULT AND DISCUSSION}

Based on the results of research conducted on coastal vegetation in the west of Sumber Jaya Village, Kampung Melayu District, Baai Island Area, Bengkulu City. The composition of the coastal vegetation at the tree level was found in 11 families, with a total of 11 species. 5 species came from the pole level, and 4 species with a total of 11 individuals from the sapling level. This shows that there is a difference with the results of observations carried out in 2017 related to the analysis of vegetation in the western area of Baai Island which found 8 tree species, 25 shrubs and saplings, and 41 herbs, small shrubs and tree seedlings. [5]. The following families are found in the data collection area, can be seen in Figure 1.

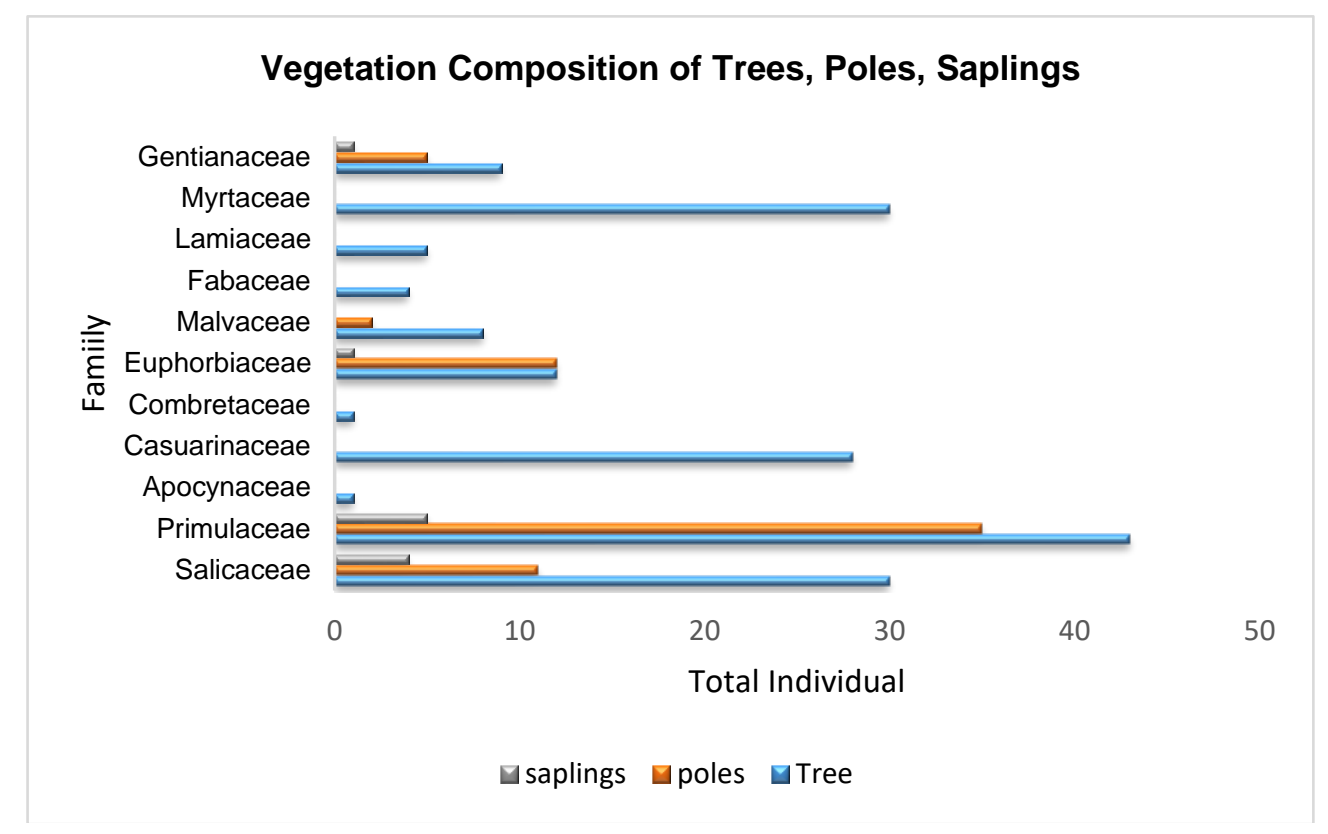

Figure 1. Vegetation Composition Of Trees, Poles, and Saplings 
Figure 1 shows the coastal vegetation around the sampling area, which is more dominated by the Primulaceae family of the Ardisia elliptica species with a total of 83 individuals and the most common tree levels. Based on Silk JWF information, Ardisia elliptica species can be found in the habitat of Sandy soils near the coast in places such as along beaches, mangrove edges, tidal riversides and peat-swamps up to $30 \mathrm{~m}$ altitude [7]. Furthermore, the composition of the second vegetation that is often found, namely Flacourtia rukam, comes from the Salicaceae family. This plant has thorny stems and is able to live in shallow sandy and moist soil conditions such as soil conditions in the observation area. Furthermore, the composition of the third vegetation that is often found is the Myrtaceae family, where this plant is distributed in predominantly tropical and subtropical areas, one of which is Indonesia. Some members of this family group have a fairly good attractiveness and economic value because they have commercial essential compounds [8].

Furthermore, the calculation results of the relative density, relative frequency, relative dominance and importance value index of each level are trees (Table 1.)

Table 1 shows that Casuarina equisetifolia has a relatively high dominance value, which indicates that the plant is dominant in coastal areas, especially in the Baai Island area west of Sumber Jaya Village, Kampung Melayu District with the highest index of importance compared to other species, amounting to 71.77. This situation has been going on since 2017, where the results of Saputra research also found Casuarina equisetifolia to dominate the Long Beach Natural Park in Bengkulu City [9]. Casuarina equisetifolia grows naturally in coastal areas, and the dominance from pine shows its ability to adapt and make better use of growing space, light, water and nutrients. However, this species is more common in tree growth rates than at the stakes and stakes. The dominance of Casuarina equisetifolia has a tendency to be replaced by other species in its habitat [4]. So that in the observation area more is found at the tree level than at the pile and stake level. The next high Importance Value Index belongs to the Ardisia elliptica species, which in the area of observation of these plants are actually found at the sapling and pole level compared to trees. The third Importance Value Index belongs to the Melaleuca leucadendron species. This plant is found in lowlands, beaches, seasonal swamps, along rivers, loam and sandy soils, is also tolerant of acidic and infertile soils [8]. Furthermore, the results of observations on pole level vegetation are shown in Table 2.

In the vegetation at the pole level, there were found as many as 5 species. Ardisia elliptica species had the highest index of importance compared to 4 other plants species, amounting to 145.15 . This plant is one of the invasive plants [10]. This species has the ability to live in shade-tolerant areas and grows well in lowlands, wet and humid areas as well as in open areas [11]. This situation is in accordance with the conditions of the discovery of Ardisia elliptica species which is about $45 \mathrm{~m}$ from the coast with open and shaded areas.

Table 3 shows that Ardisia elliptica also dominates at the sapling level, with the highest index of importance, namely 95.45. Its ability to tolerate various environmental conditions as well as seed dispersal is assisted by birds and some mammals, making it one of the invasive plants because it is able to form monotypic stands, especially in humid areas so as to replace native vegetation [12]. Apart from Ardisia elliptica, three other vegetation were also found, such as Flacourtia rukam, Fagraea racemose, Macaranga tanarius. This plant is able to grow in the sandy soil conditions found in the sampling area.

Table 1. Vegetation of Tree Levels in Baai Island Area

\begin{tabular}{|c|l|l|c|c|c|c|}
\hline NO & Species & Family & DsR \% & FR\% & DR\% & INP \\
\hline 1 & Casuarina equisetifolia & Casuarinaceae & 16.37 & 12.00 & 43.40 & 71.77 \\
\hline 2 & Ardisia elliptica & Primulaceae & 25.15 & 16.00 & 8.69 & 49.84 \\
\hline 3 & Melaleuca leucadendron & Myrtaceae & 17.54 & 12.00 & 19.65 & 49.19 \\
\hline 4 & Flacourtia rukam & Salicaceae & 17.54 & 16.00 & 12.66 & 46.21 \\
\hline 5 & Hibiscus tiliaceus & Malvaceae & 4.68 & 14.00 & 3.21 & 21.89 \\
\hline 6 & Macaranga tanarius & Euphorbiaceae & 7.02 & 6.00 & 1.96 & 14.98 \\
\hline 7 & Acasia mangium & Fabaceae & 2.34 & 8.00 & 3.69 & 14.03 \\
\hline 8 & Vitex pubescens & Lamiaceae & 2.92 & 6.00 & 3.86 & 12.78 \\
\hline 9 & Fagraea racemosa & Gentianaceae & 5.26 & 6.00 & 1.51 & 12.78 \\
\hline 10 & Terminalia catappa & Combretaceae & 0.58 & 2.00 & 1.28 & 3.86 \\
\hline 11 & Cerbera manghas & Apocynaceae & 0.58 & 2.00 & 0.08 & 2.66 \\
\hline & & 100 & 100 & 100 & 300 \\
\hline
\end{tabular}


Table 2. Vegetation of Pole Levels in Baai Island Area

\begin{tabular}{|c|l|l|c|c|c|c|}
\hline NO & Species & Family & DsR\% & FR\% & DR\% & INP \\
\hline 1 & Ardisia elliptica & Primulaceae & 53.85 & 38.89 & 52.42 & 145.15 \\
\hline 2 & Macaranga tanarius & Euphorbiaceae & 18.46 & 22.22 & 16.49 & 57.17 \\
\hline 3 & Flacourtia rukam & Salicaceae & 16.92 & 16.67 & 18.35 & 51.94 \\
\hline 4 & Fagraea racemose & Gentianaceae & 7.69 & 11.11 & 9.44 & 28.24 \\
\hline 5 & Hibiscus tiliaceus & Malvaceae & 3.08 & 11.11 & 3.30 & 17.49 \\
\hline \multicolumn{2}{|c|}{ TOTAL } & 100 & 100 & 100 & 300 \\
\hline
\end{tabular}

Table 3. Vegetation of Sapling Levels in Baai Island Area

\begin{tabular}{|c|l|l|c|c|c|c|}
\hline NO & Species & Family & DsR\% & FR\% & DR\% & INP \\
\hline 1 & Ardisia elliptica & Primulaceae & 45.45 & 50.00 & 35,04 & 95.45 \\
\hline 2 & Flacourtia rukam & Salicaceae & 36.36 & 25.00 & 42,52 & 61.36 \\
\hline 3 & Fagraea racemosa & Gentianaceae & 9.09 & 12.50 & 11,22 & 21.59 \\
\hline 4 & Macaranga tanarius & Euphorbiaceae & 9.09 & 12.50 & 11,22 & 21.59 \\
\hline & TOTAL & 100 & 100 & 100 & 200 \\
\hline
\end{tabular}

The results of the calculation of the Shannon-Wiener diversity index at each growth level show a value of $<1.0$, which means that the diversity is low and less stable. However, among the three levels, the highest value was found at the tree level of 0.86 (Figure 2.), meaning that species interactions that occur in tree communities are more complex than at the poles and saplings level.

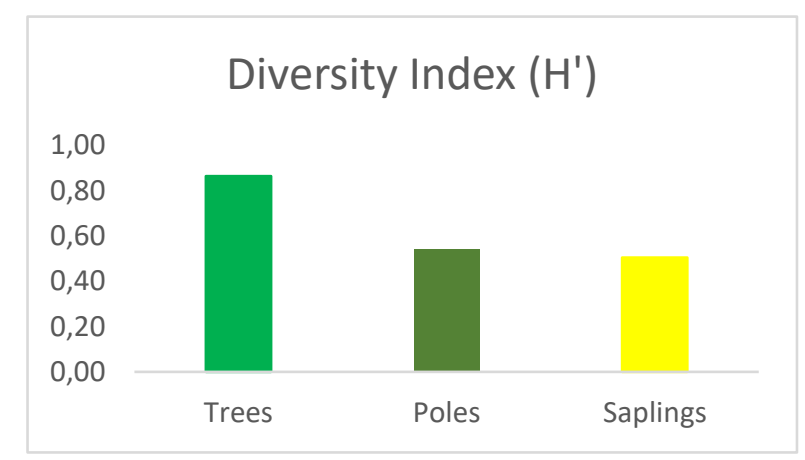

Figure 2. Shannon-Wiener Diversity Index $\left(\mathrm{H}^{\prime}\right)$ of each level

Environmental factors around the habitat can affect the existence of the vegetation in which there are interactions between living organisms, and interactions between organisms and their environment. Changes that occur can also be caused by positive or negative responses to these interactions, for example, growth, development, mortality, birthrate, and migration [2].

\section{CONCLUSION}

The results of research conducted on coastal vegetation in the west of Sumber Jaya Village, Kampung Melayu District, Baai Island Area, Bengkulu City. Shows the composition of coastal vegetation at the tree level, found 11 families, with a total of 11 species. 5 species came from the pole level, and 4 species with a total of 11 individuals from the sapling level. The highest importance value index at the tree level was obtained by the Casuarina equisetifolia species and the INP value of the stake and stake level was obtained by the Ardisia elliptica species. Related to the calculation results, the Shannon-Wiener diversity index $\left(\mathrm{H}^{\prime}\right)$, of all growth rates demonstrate the value of $<1.0$ means low diversity.

\section{REFERENCES}

[1] Balai Konservasi Sumber Daya Alam Bengkulu. 2017, Accessed on 26 Oktober 2020 https://bksdabengkulu.id/profil/kawasan/5 [In Bahasa Indonesia]

[2] Tuheteru, FD dan Mahfudz, Ekologi, Manfaat \& Rehabilitasi, Hutan Pantai Indonesia. Balai Penelitian Kehutanan Manado. Manado, Indonesia. 178 hal. 2012. [In Bahasa Indonesia]

[3] Suwarsono, Supriati, Suwardi. Zonasi Karakteristik Kecepatan Abrasi dan Rancangan Teknik Penanganan Jalan Lintas Barat Bengkulu Bagian Utara Sebagai Jalur Transportasi Vital. Makara Teknol. 15(1) (2011) 31-38. [In Bahasa Indonesia]

[4] Farma A, Hikmat A, Soekmadi R. Struktur dan Komposisi Vegetasi di Habitat Cemara Laut (Casuarina equisetifolia L.) pada Tiga Kawasan Konservasi di Provinsi Bengkulu. JPSL 9(3): 596607. http://dx.doi.org/10.29244/jpsl.9.3.596-607.

[5] Kusmana C., Metode Survey Vegetasi. Institut Pertanian Bogor Press. Bogor. 1997. [In Bahasa Indonesia] 
[6] Fachrul, M.F. Metode Sampling Bioekologi. Bumi Aksara. Jakarta. 2007. [In Bahasa Indonesia]

[7] Tropical Plants Database, Ken Fern. tropical.theferns.info. Accessed on 02 May 2021 tropical.theferns.info/viewtropical.php?id=Ardisia + elliptica

[8] Barbosa LCA, Cleber JS, Róbson RT, Renata MSAM, Antonio LP. Chemistry and Biological Activities of Essensial Oil from Melaleuca $L$. Spesies. Agriculturae Conspectus Scientificus. 2013;78(1):11-23.

[9] Saputra, Andi and Wiryono, Wiryono and M.Fajrin, Hidayat, Analisis Vegetasi Hutan Di Bagian Barat Laut TWA Pantai Panjang Pulau Baai Bengkulu. Undergraduated thesis, Agriculture (General), Universitas Bengkulu. 2017. [In Bahasa Indonesia]

[10] Ardisia elliptica (shoebutton ardisia) [original text by Lowe S, Browne M, Boudjelas S, Poorter M de, 100 of the world's Worst Invasive Alien Species. A Selection From The Global Invasive Species Database. 100 of The World's Worst Invasive Alien Species. A Selection From The Global Invasive Species Database. Auckland, New Zealand: ISSG, 2004, 12 pp. http://issg.org/booklet.pdf] In: Invasive Species Compendium. Wallingford, UK: CAB International. www.cabi.org/isc. (Accessed on 29 March 2021)

[11] Reichard, Sarah, Assessing the potential of invasiveness in woody plants introduced in North America. University of Washington Ph.D., 1994, dissertation.

https://www.invasiveplantatlas.org/list.html?id=13 1 (Accessed on 30 March 2021)

[12] CABI, 2020. Ardisia elliptica. In: Invasive Species Compendium. Wallingford, UK: CAB International. https://www.cabi.org/isc/datasheet/1 08066 (Accessed on 29 March 2021) 